\title{
Protective Role of Nuclear Factor E2-Related Factor 2 against Acute Oxidative Stress-Induced Pancreatic $\beta$-Cell Damage
}

\author{
Jingqi Fu, ${ }^{1}$ Hongzhi Zheng, ${ }^{2}$ Huihui Wang, ${ }^{1}$ Bei Yang, ${ }^{3}$ \\ Rui Zhao, ${ }^{4}$ Chunwei Lu, ${ }^{1}$ Zhiyuan Liu, ${ }^{1}$ Yongyong Hou, ${ }^{1}$ Yuanyuan Xu, ${ }^{1}$ \\ Qiang Zhang, ${ }^{5}$ Weidong $Q \mathbf{u},{ }^{6}$ and Jingbo $\mathbf{P i}^{1}$ \\ ${ }^{1}$ Program of Environmental Toxicology, School of Public Health, China Medical University, No. 77 Puhe Road, \\ Shenyang North New Area, Shenyang, Liaoning 110122, China \\ ${ }^{2}$ The First Affiliated Hospital, China Medical University, 155 Nanjingbei Street, Heping District, Shenyang, Liaoning 110001, China \\ ${ }^{3}$ Department of Histology and Embryology, School of Basic Medical Sciences, China Medical University, No. 77 Puhe Road, \\ Shenyang North New Area, Shenyang, Liaoning 110122, China \\ ${ }^{4}$ School of Forensic Medicine, China Medical University, No. 77 Puhe Road, Shenyang North New Area, Shenyang, \\ Liaoning 110122, China \\ ${ }^{5}$ Institute for Chemical Safety Sciences, The Hamner Institutes for Health Sciences, 6 Davis Drive, \\ Research Triangle Park, NC 27709, USA \\ ${ }^{6}$ Key Laboratory of Public Health Safety of Ministry of Education, School of Public Health, Fudan University, P.O. Box 249, \\ 138 Yi Xue Yuan Road, Shanghai 200032, China \\ Correspondence should be addressed to Jingbo Pi; jpi@mail.cmu.edu.cn
}

Received 18 December 2014; Revised 16 March 2015; Accepted 18 March 2015

Academic Editor: Silvana Hrelia

Copyright (C) 2015 Jingqi Fu et al. This is an open access article distributed under the Creative Commons Attribution License, which permits unrestricted use, distribution, and reproduction in any medium, provided the original work is properly cited.

\begin{abstract}
Oxidative stress is implicated in the pathogenesis of pancreatic $\beta$-cell dysfunction that occurs in both type 1 and type 2 diabetes. Nuclear factor E2-related factor 2 (NRF2) is a master regulator in the cellular adaptive response to oxidative stress. The present study found that MIN6 $\beta$-cells with stable knockdown of Nrf2 (Nrf2-KD) and islets isolated from Nrf2-knockout mice expressed substantially reduced levels of antioxidant enzymes in response to a variety of stressors. In scramble MIN6 cells or wild-type islets, acute exposure to oxidative stressors, including hydrogen peroxide $\left(\mathrm{H}_{2} \mathrm{O}_{2}\right)$ and S-nitroso- $\mathrm{N}$-acetylpenicillamine, resulted in cell damage as determined by decrease in cell viability, reduced ATP content, morphology changes of islets, and/or alterations of apoptotic biomarkers in a concentration- and/or time-dependent manner. In contrast, silencing of Nrf2 sensitized MIN6 cells or islets to the damage. In addition, pretreatment of MIN6 $\beta$-cells with NRF2 activators, including CDDO-Im, dimethyl fumarate (DMF), and tert-butylhydroquinone (tBHQ), protected the cells from high levels of $\mathrm{H}_{2} \mathrm{O}_{2}$-induced cell damage. Given that reactive oxygen species (ROS) are involved in regulating glucose-stimulated insulin secretion (GSIS) and persistent activation of NRF2 blunts glucose-triggered ROS signaling and GSIS, the present study highlights the distinct roles that NRF2 may play in pancreatic $\beta$-cell dysfunction that occurs in different stages of diabetes.
\end{abstract}

\section{Introduction}

Pancreatic $\beta$-cell damage is the fundamental pathogenesis of type 1 diabetes, which is mediated by an autoimmune and inflammatory process [1]. Disruption of pancreatic $\beta$ cells leading to islet dysfunction and reduced $\beta$-cell mass is also implicated in type 2 diabetes [2]. Oxidative stress, which is characterized by increased production of reactive oxygen species (ROS) and/or reactive nitrogen species (RNS), is involved in the destruction of $\beta$-cells in different stages of both type 1 and type 2 diabetes. Although ROS, in particular hydrogen peroxide $\left(\mathrm{H}_{2} \mathrm{O}_{2}\right)$, may function as intracellular secondary messenger mediating glucose-stimulated insulin secretion (GSIS) in pancreatic $\beta$-cells [3-5], excessive and 
persistent production of ROS results in oxidative damage and disrupts the function of proteins, nucleic acids, and fatty acids $[6,7]$.

In type 1 diabetes, pancreatic $\beta$-cell failure is mediated by inflammatory cytokines, including interleukin- $1 \beta$ (IL-1 $\beta$ ), tumor necrosis factor- $\alpha$ (TNF- $\alpha$ ), and interferon- $\gamma$ (IFN- $\gamma$ ), which may stimulate production of RNS, especially nitric oxide (NO) [8]. Similar to $\mathrm{H}_{2} \mathrm{O}_{2}$, $\mathrm{NO}$ also functions as an important messenger molecule that mediates a variety of physiological processes, including vasodilation [9], neurotransmission [10], and immunity response [11]. However, persistent elevation of endogenous or exogenous RNS may also induce cytotoxic effects in various cell types. High levels of NO disrupt energy metabolism, induce DNA damage, activate poly(ADP-ribose) polymerase (PARP), and/or dysregulate cytosolic calcium leading to cell necrosis and apoptosis $[12,13]$.

Although ROS and RNS participate in various cellular response pathways, they both induce DNA damage and reduce cell viability at high levels [14]. Of interest, cells have acquired complicated mechanisms to localize endogenous ROS and/or RNS distribution and defend against exogenous ROS and/or RNS toxicity. Among them, transcriptional signaling through the antioxidant response element (ARE), orchestrated by the nuclear factor E2-related factor 2 (NRF2), is a major cellular defense mechanism against oxidative or electrophilic stress. Nrf2-deficient animals and cells have been shown to display reduced antioxidant response and become intolerant to oxidative or electrophilic stress-induced damage [15-19]. Compared with other cell types and tissues, pancreatic $\beta$-cells express low levels of many antioxidant enzymes and thus are hypothesized to be susceptible to oxidative damage induced by ROS and/or RNS [20]. However, the role of NRF2-mediated antioxidant response in acute ROS or RNS-induced pancreatic $\beta$-cell damage has not been thoroughly investigated.

In the current study, we hypothesized that NRF2 plays a protective role against acute oxidative stress-induced pancreatic $\beta$-cell damage, a process that may occur in type 1 and type 2 diabetes. To test the hypothesis, we determined the susceptibility of Nrf2-knockout (Nrf2-/-) islets and Nrf2knockdown (Nrf2-KD) MIN6 cells to high levels of oxidative stressors-induced cell damage. In addition, we investigated the protective effects of preactivation of NRF2 on acute oxidative stress-induced cell damage.

\section{Materials and Methods}

2.1. Cell Culture and Reagents. MIN6 cells at passage 30 were kindly gifted by Dr. Marcia Haigis (Harvard University, USA) and maintained in Dulbecco's modified Eagle's medium (DMEM) containing $25 \mathrm{mmol} / \mathrm{l}$ glucose, supplemented with $15 \%$ fetal bovine serum (FBS), 100 units $/ \mathrm{mL}$ penicillin, $100 \mu \mathrm{g} / \mathrm{mL}$ streptomycin, $2 \mathrm{mmol} / \mathrm{l} \mathrm{L}$-glutamine, and $5 \mu \mathrm{L} / 1 \beta$ mercaptoethanol in humidified $5 \% \mathrm{CO}_{2}, 95 \%$ air at $37^{\circ} \mathrm{C}$ as previously described [21]. The cells at passages $42-48$ were used in the current study. There was no significant difference among the passages in their glucose responsiveness and cytotoxic susceptibility to a variety of stressors. $\mathrm{H}_{2} \mathrm{O}_{2}$ solution, glucose oxidase, S-nitroso- $\mathrm{N}$-acetylpenicillamine (SNAP), sodium arsenite, tert-butylhydroquinone (tBHQ), $\beta$-mercaptoethanol, hexadimethrine bromide, dimethyl fumarate (DMF), and 1-[2-cyano-3,12-dioxooleana-1,9(11)-dien-28oyl]imidazole (CDDO-Im) were purchased from Sigma (Saint Louis, MO).

2.2. Establishment of Stable Cell Lines and Measurement of Luciferase Activity. MIN6 cells were transduced with Lentivirus containing shRNA against Nrf2 (SHVRSNM_010902, Sigma), scrambled nontarget negative control (SHC002V, Sigma), or ARE-luciferase reporter (SABiosciences, Frederick, MD) as previously described [17]. The luciferase activity of ARE-luciferase reporter cells was determined by Luciferase Reporter Assay System (Promega, Madison, WI) and normalized to cell viability with the same treatment as detailed in our previous studies [22].

2.3. Animals and Islet Isolation. Nrf2-/- mice developed as described previously [23] were kindly provided by Dr. Masayuki Yamamoto (Tohoku University, Japan). Wild-type $(\mathrm{Nrf2+} /+)$ and Nrf2-/- mice were maintained on normal chow diet. All animal experiments were approved by the Institutional Animal Care and Use Committee of China Medical University. Pancreatic islets were isolated from 8-12week-old Nrf2+/+ and Nrf2-1- mice by in situ collagenase P (Roche, Switzerland) perfusion of pancreas under a dissecting microscope, as described previously [4]. Isolated islets were cultured in RPMI 1640 supplemented with $10 \mathrm{mmol} / \mathrm{l}$ glucose, 10\% FBS, 25 mmol/l HEPES, 2 mmol/l L-glutamine, $100 \mathrm{U} / \mathrm{mL}$ penicillin, and $100 \mu \mathrm{g} / \mathrm{mL}$ streptomycin. All the isolated islets were cultured for $48 \mathrm{hrs}$ before in vitro experiments.

2.4. Measurement of Intracellular Glutathione (GSH). MIN6 cells were sonicated in cold PBS immediately after collection. The whole cell extracts were obtained by centrifugation at $12,000 \times \mathrm{g}$ for $5 \mathrm{~min}$, and protein concentration was determined by a BCA assay kit (Pierce Biotechnology, Rockford, IL). Following an immediate deproteinization with metaphosphoric acid (final concentration at 5\%), levels of total GSH were measured using a BIOXYTECH GSH/GSSG412 kit (OxisResearch, Portland, OR) according to the manufacturer's protocol. Of note, the levels of oxidized GSH (GSSG) in MIN6 cells were too low to be measured.

2.5. Determination of Intracellular Peroxide. Levels of intracellular peroxide were measured by flow cytometry (Becton Dickinson FACSort, Becton Dickinson, San Jose, CA) using a fluorescent probe 5-(and-6)-chloromethyl-2' $2^{\prime}$-dichlorodihydrofluorescein diacetate, acetyl ester (CM- $\mathrm{H}_{2} \mathrm{DCFDA}$, Molecular Probes, Eugene, OR) as described previously [4]. The loading concentration of CM- $\mathrm{H}_{2}$ DCFDA was $2 \mu \mathrm{M}$ and the preloading times were $30 \mathrm{~min}$. In the measurements, dead cells and clumps were eliminated based upon Forward Scatter versus Side Scatter measurements, and untreated cells provided a source of comparison. 
TABLE 1: Primer sequences for real-time RT-PCR.

\begin{tabular}{lll}
\hline Gene & Sense & Antisense \\
\hline $18 s$ & CGAACGTCTGCCCTATCAACTT & CCGGAATCGAACCCTGATT \\
Gclc & TGGCCACTATCTGCCCAATT & GTCTGACACGTAGCCTCGGTAA \\
$H m o x-1$ & CCTCACTGGCAGGAAATCATC & CCTCGTGGAGACGCTTTACATA \\
$N q o 1$ & TATCCTTCCGAGTCATCTCTAGCA & TCTGCAGCTTCCAGCTTCTTG \\
$N r f 2$ & CGAGATATACGCAGGAGAGGTAAGA & GCTCGACAATGTTCTCCAGCTT \\
$P r d x 1$ & TCCCAAGCGCACCATTG & AGGCCCCTGAAAGAGATACCTT \\
Sod 1 & GTGATTGGGATTGCGCAGTA & TGGTTTGAGGGTAGCAGATGAGT \\
Srxn1 & CCGTTCTTCAGTCTATGAAAAGATAACA & CCGAGTCCATCTTTCTTACTTCCT \\
\hline
\end{tabular}

2.6. Quantitative Real-Time RT-PCR. Total RNA was extracted from MIN6 cells and isolated islets with TRIzol reagent (Life Technologies, Carlsbad, CA) and purified by RNeasy Mini kit and RNase-Free DNase Set (Qiagen, Valencia, CA). cDNA was prepared by MuLV reverse transcriptase using Oligo (dT) primers (Applied Biosystems, Foster City, CA). Relative mRNA abundance was determined by quantitative real-time PCR with SYBR green detection using ABI PRISM 7900HT Fast Real-Time PCR System as described previously [24]. The primers were designed using the Primer Express (Applied Biosystems) and synthesized by MWGBIOTECH Inc. (High Point, NC). The sequences are shown in Table 1.

2.7. Analysis of Proteins. Isolation of cell fraction and immunoblotting were performed as detailed previously [24, 25]. Briefly, whole cell extracts were prepared by sonication with cell lysis buffer (Cell Signaling, Technology, Inc., Beverly, MA) with Protease Inhibitor Cocktail (Sigma) and Phosphatase Inhibitor Cocktail I (Sigma). Nuclear fractions were separated by the TransFactor Extraction Kit (BD Biosciences Clontech, Palo Alto, CA) according to the manufacturer's protocols. Protein concentrations were determined by BCA assay kit (Pierce), and all the protein fractions were stored at $-80^{\circ} \mathrm{C}$ until use. Protein extracts were boiled and resolved on Novex Tris-Glycine Gel (Life Technologies), transferred onto nitrocellulose membranes (Bio-Rad) for immunoblotting, and visualized by ECF substrate (GE Healthcare). Blot imaging and quantification were performed using a Typhoon scanner and the Bio-Rad TDS Quantity One software. Antibodies for NRF2 (sc-13032; 1:500) were purchased from Santa Cruz Biotechnology, Inc. (Santa Cruz, CA). Antibodies for cleaved Caspase-3 (number 9661, 1:1000), cleaved PARP (number 9542, 1:1000), and Caspase-3 (number 9662, $1: 1000)$ were from Cell Signaling Technology, Inc. (Danvers, MA). Antibodies for Lamin A (L1293; $1: 2500)$ and $\beta$-Actin (A1978; $1: 2000)$ were purchased from Sigma.

2.8. Cell Viability and Cytotoxicity Assay. Cell viability was determined as described previously [26]. Briefly, 10,000 cells per well were plated into a 96-well plate. Following a $24 \mathrm{hr}$ culture, medium was replaced with fresh medium containing various stressors at the appropriate concentrations. Cells were treated for indicated time with stressors and followed by an immediate measurement for cell viability by using the nonradioactive cell proliferation assay kit (Promega, Madison, WI). Intracellular ATP levels were measured using an ATP Bioluminescent Somatic Cell Assay Kit (Sigma).

2.9. Statistical Analyses. All statistical analyses were performed using Graphpad Prism 4 (GraphPad Software, San Diego, CA). Statistical significance was defined as $P<$ 0.05 . Data are expressed as mean \pm SD. For comparisons between and among groups, Student's $t$-test and one-way ANOVA with Bonferroni post hoc testing were performed, respectively.

\section{Results}

3.1. Stable Knockdown of Nrf2 in MIN6 Cells Results in Attenuated Antioxidant Response. To investigate the role of NRF2 in acute oxidative stress-induced $\beta$-cell damage, a line of MIN6 cells with stable silencing of Nrf2 was developed. As shown in Figure 1(a), lentiviral shRNA-mediated stable knockdown of Nrf2 in MIN6 cells resulted in 70\% reduction in mRNA expression of Nrf2 compared to the control cells that were expressed scrambled nontarget negative control shRNA (scramble). In agreement with the reduction of Nrf2 mRNA, Nrf2-KD cells displayed substantially reduced protein expression of NRF2 under vehicle and arseniteor tBHQ-challenged conditions (Figure 1(b)). In scramble cells, the protein levels of NRF2 in nuclear fractions were dramatically increased by arsenite or tBHQ treatments, whereas the inductions were almost totally diminished in Nrf2-KD cells (Figure 1(b)). In addition, Nrf2-KD cells showed reduced expression of two major ARE-dependent genes glutamate-cysteine ligase catalytic subunit $(G c l c)$ and $\mathrm{NAD}(\mathrm{P}) \mathrm{H}$ quinone oxidoreductase 1 (Nqo1) under basal or tBHQ-challenged conditions (Figure $1(\mathrm{c})$ ). Furthermore, silencing of $\mathrm{Nrf} 2$ resulted in significantly decreased intracellular levels of GSH (Figure 1(d)) and elevation of intracellular ROS (Figure 1(e)).

3.2. Nrf2-Deficient $\beta$-Cells Are Vulnerable to Acute Oxidative Stress-Induced Cell Damage. To test the hypothesis that NRF2 plays a protective role against the cytotoxicity of acute oxidative stress in pancreatic $\beta$-cells, we investigated the susceptibility of Nrf2-KD MIN6 cells and Nrf2-/- mouse islets to $\mathrm{H}_{2} \mathrm{O}_{2}$-induced cell damage. As shown in Figure 2, Nrf2$\mathrm{KD}$ cells were more vulnerable to $\mathrm{H}_{2} \mathrm{O}_{2}$ solution-induced 


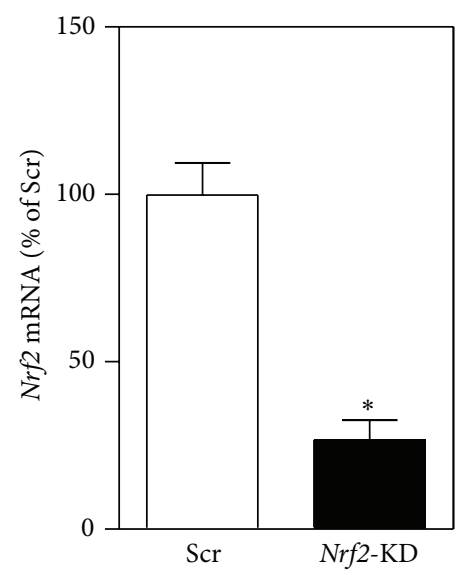

(a)

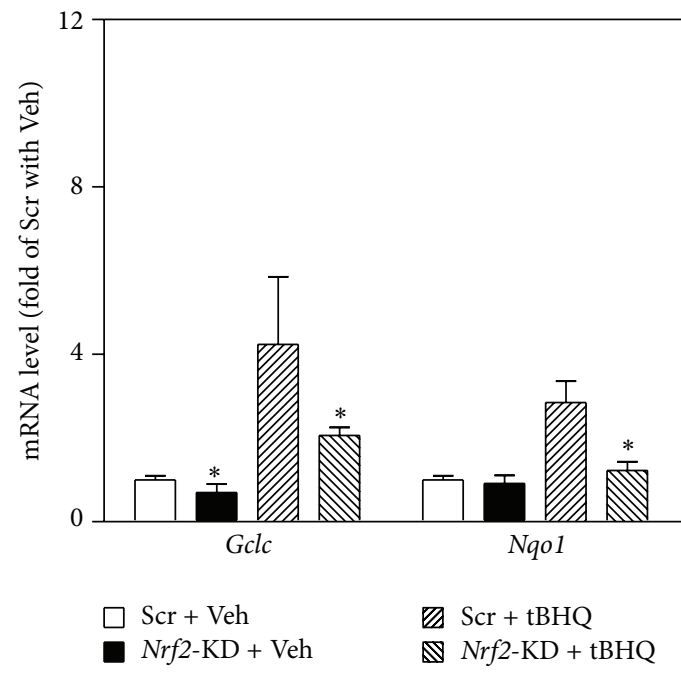

(c)

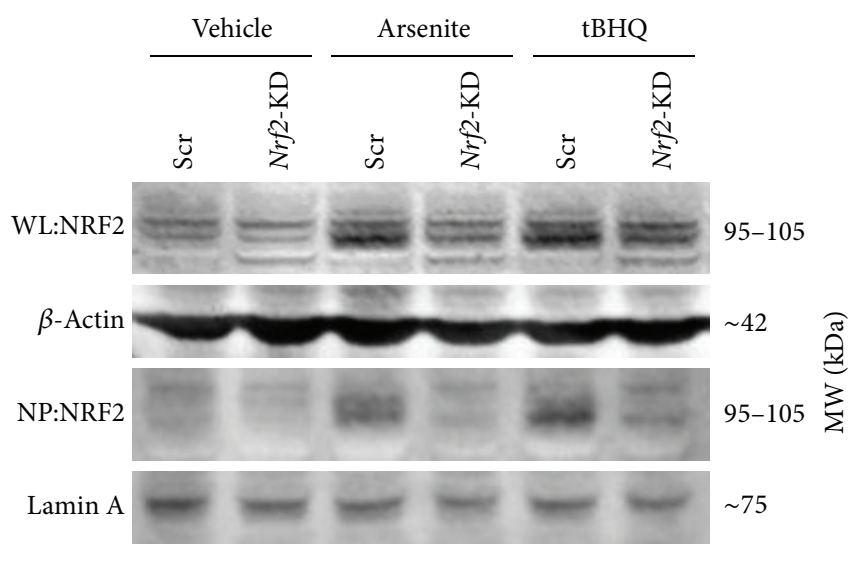

(b)
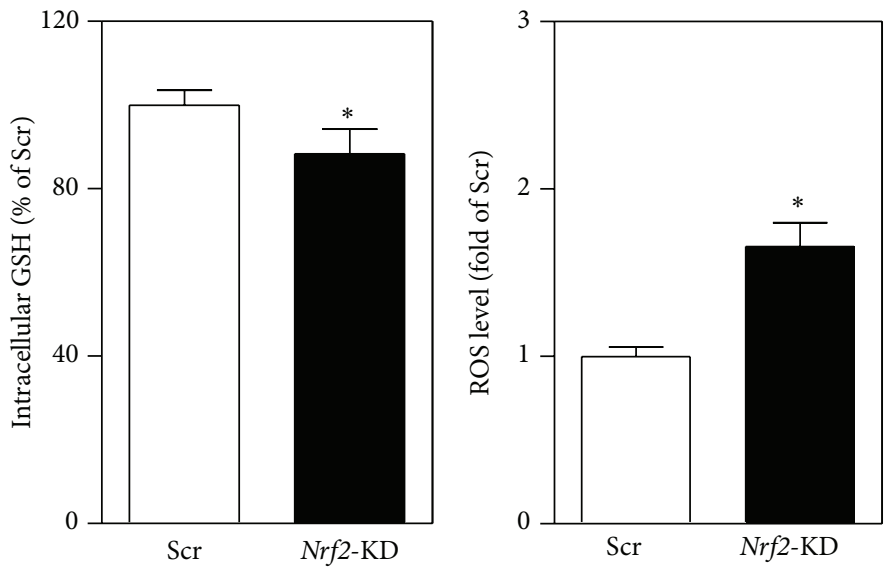

(d)

(e)

FIGURE 1: Stable knockdown of Nrf2 results in reduced expression of ARE-dependent genes, decreased intracellular GSH, and elevated intracellular ROS levels in MIN6 cells. (a) mRNA expression of Nrf2 in cells transduced with lentiviral shRNA targeted against mouse Nrf2 (Nrf2-KD) or scrambled nontarget negative control (Scr). (b) Reduced protein expression of NRF2 in Nrf2-KD cells under basal and arsenite $(5 \mu \mathrm{M})$, tert-butylhydroquinone (tBHQ, $50 \mu \mathrm{M})$ treated conditions. Cells were exposed to the chemicals for 6 hrs. Whole cell lysates (WL) and nuclear protein (NP) were used for immunoblotting, and $\beta$-Actin and Lamin A were used as loading controls, respectively. (c) Expression of ARE-dependent genes under vehicle (Veh) and tBHQ treated conditions. Cells were treated with the tBHQ for 6 hrs. The expression of Gclc and Nqo1 was measured by real-time RT-PCR. (d) Intracellular GSH levels. (e) Intracellular ROS levels. Values in (a), (c), (d), and (e) are means \pm SD. $n=3-6 .{ }^{*} P<0.05$ versus Scr with the same treatment.

reduction in cell viability (Figure $2(\mathrm{a}))$ and ATP content (Figure 2(b)). In response to glucose oxidase, which is a mild and long-lasting $\mathrm{H}_{2} \mathrm{O}_{2}$-generating system that catalyzes the oxidation of glucose to produce $\mathrm{H}_{2} \mathrm{O}_{2}, \mathrm{Nrf2-KD}$ MIN6 cells also showed an elevated susceptibility to its cytotoxicity (Figure 2(c)). Of note, application of glucose oxidase may reduce the concentrations of glucose in media, which may directly affect cell viability. Thus, the glucose oxidase-induced cytotoxicity in Scr and Nrf2-KD cells could be a mixed effect of glucose removal and $\mathrm{H}_{2} \mathrm{O}_{2}$ exposure. Consistent with the assays for cytotoxicity, acute $\mathrm{H}_{2} \mathrm{O}_{2}$ exposure resulted in dramatically increased levels of multiple apoptotic markers, including cleaved Caspase-3 (C-Casp-3) and cleaved PARP (C-PARP), in Scr and Nrf2-KD cells in a concentration- and time-dependent fashion (Figures 2(d) and 2(e)). Importantly, the $\mathrm{H}_{2} \mathrm{O}_{2}$ exposure-induced increase of these apoptotic markers in Nrf2-KD was substantially higher than that in Scr cells (Figures 2(d) and 2(e)), indicating that deficiency of $\mathrm{Nrf2}$ makes $\beta$-cells susceptible to $\mathrm{H}_{2} \mathrm{O}_{2}$ exposure-induced apoptosis.

To ascertain the involvement of NRF2-mediated antioxidant response in protection against acute $\mathrm{H}_{2} \mathrm{O}_{2}$-induced cell damage, the expression of multiple antioxidant genes, including Gclc, sulfiredoxin (Srxn1), superoxide dismutase-1 (Sod1), peroxiredoxin-1 (Prdx1), Nqol, and heme oxygenase 1 (Hmox-1), was determined in Nrf2-KD and scramble MIN6 cells under basal and $\mathrm{H}_{2} \mathrm{O}_{2}$-challenged conditions. As shown in Figure 3, mRNA levels of Gclc, Srxn1, Sod1, and Prdx1 


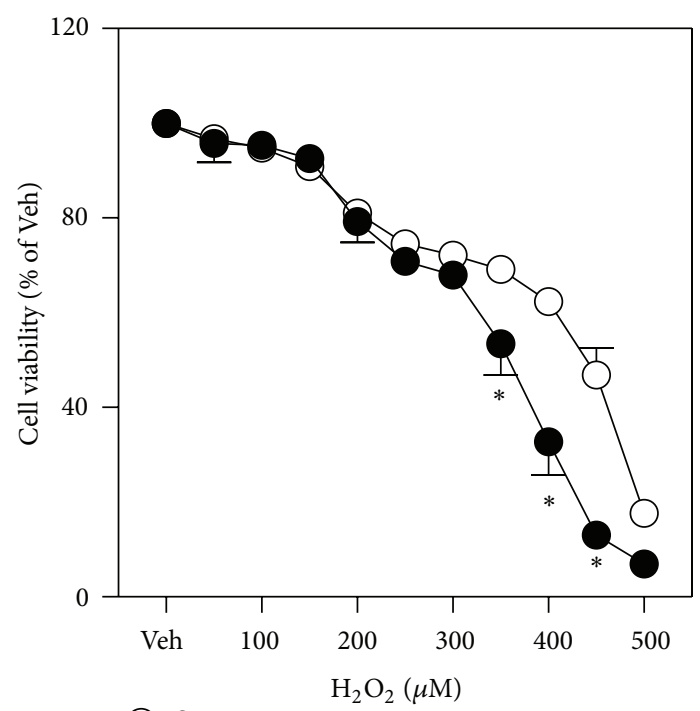

- $\mathrm{Scr}$

- Nrf2-KD

(a)

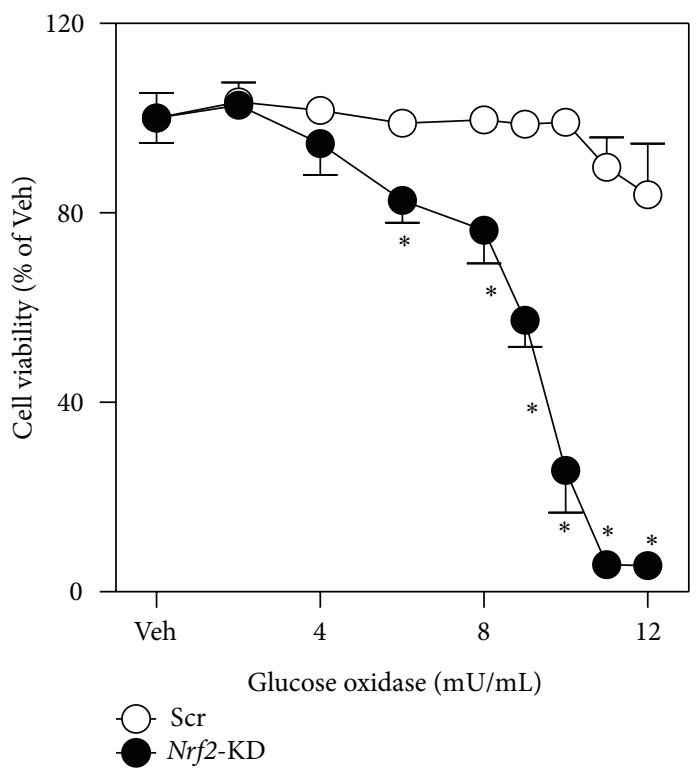

(c)

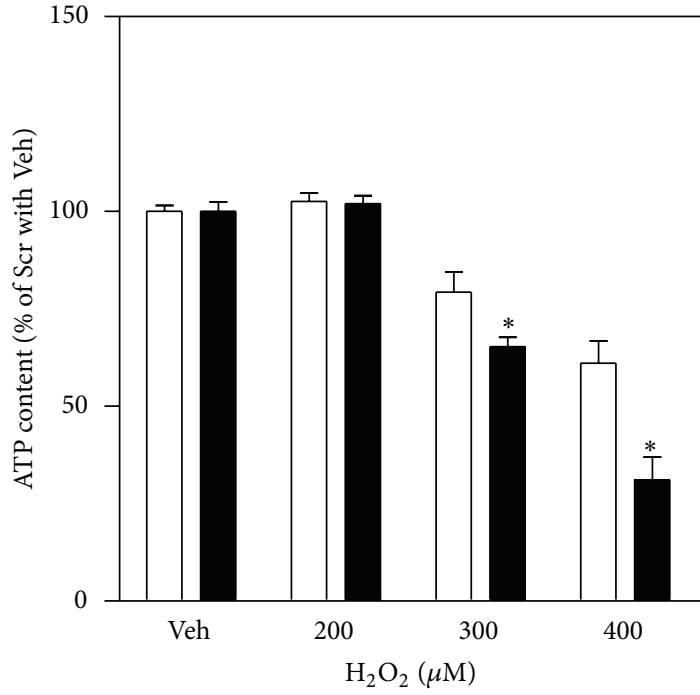

$\square \mathrm{Scr}$

- Nrf2-KD

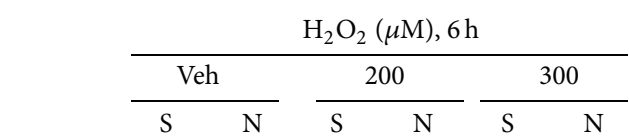

C-Casp-3 $2 \sim 19$

Casp-3

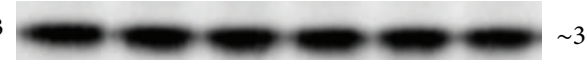

30 疋

C-PARP

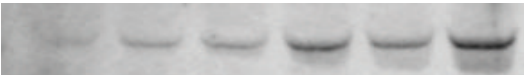

$\sim 89 \sum$

$\beta$-Actin

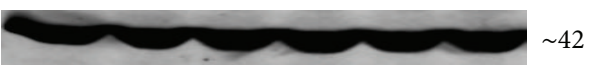

(d)

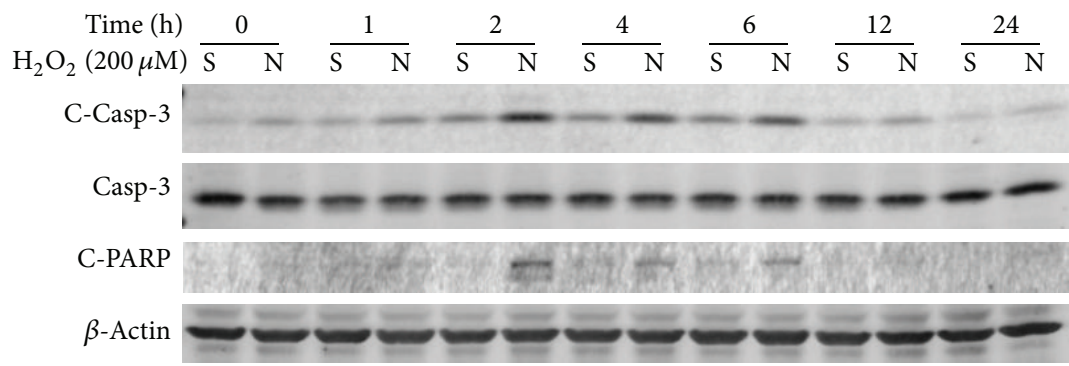

(e)

Figure 2: Nrf2 silencing sensitizes MIN6 cells to oxidative stressor-induced cell damage. ((a) and (c)) Concentration-dependent decrease of cell viability in Nrf2-KD and Scr cells caused by $\mathrm{H}_{2} \mathrm{O}_{2}$ (a) and glucose oxidase (c) exposure. Cell viability was assessed by MTT assay following a $24 \mathrm{hr}$ treatment. (b) ATP content in Scr and Nrf2-KD cells following a $24 \mathrm{hr} \mathrm{H}_{2} \mathrm{O}_{2}$ treatment. ((d) and (e)) Immunoblotting of cleaved Caspase-3 (C-Casp-3), Caspase-3 (Casp-3), and cleaved PARP (C-PARP) in MIN6 cells exposed to $\mathrm{H}_{2} \mathrm{O}_{2}$ for indicated time and concentrations. $\beta$-Actin was used as a loading control. S, Scr; N, Nrf2-KD. Values in (a), (b), and (c) are means \pm SD. $n=3-6 .{ }^{*} P<0.05$ versus Scr with the same treatment. 

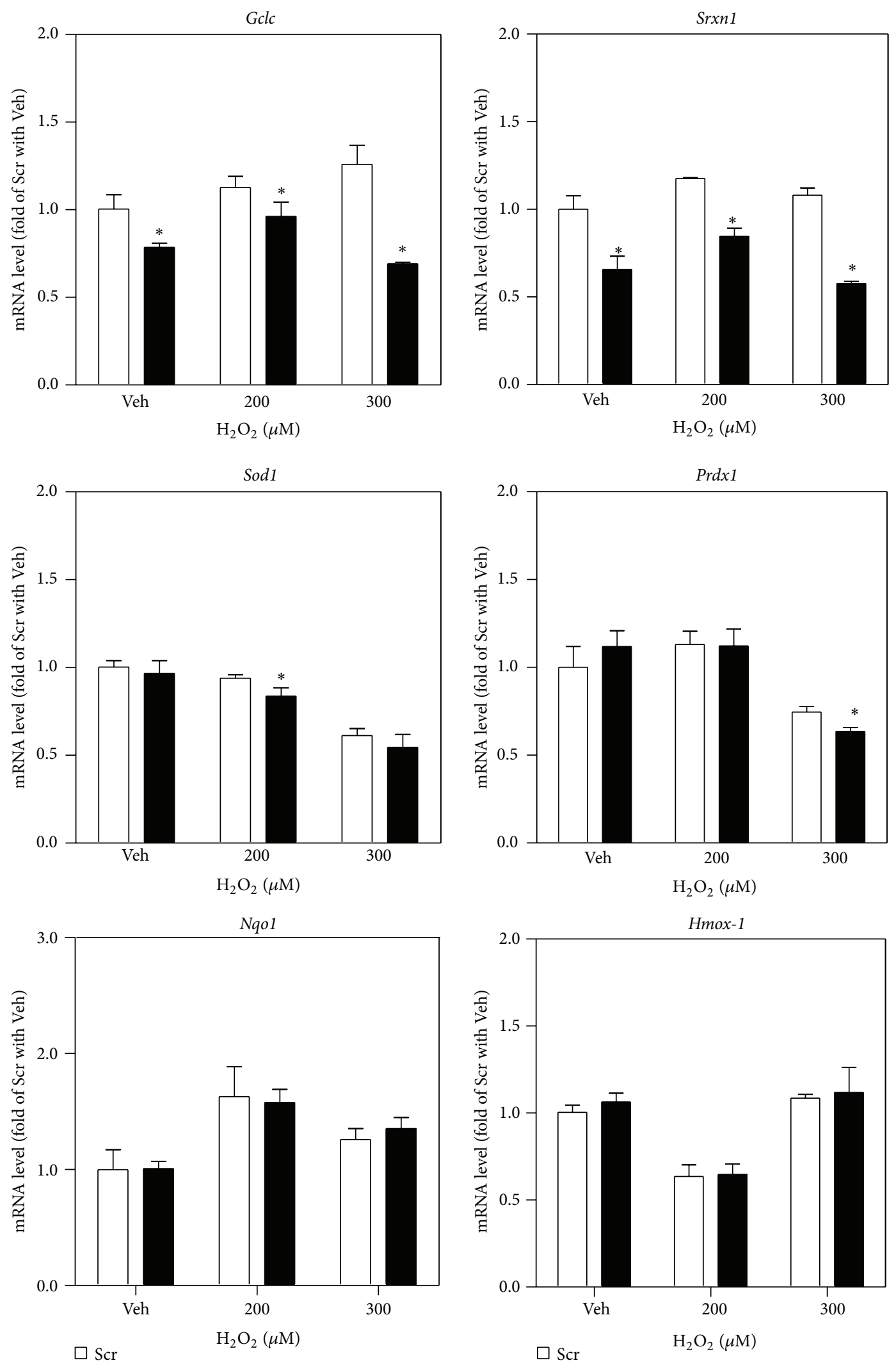

$\mathrm{H}_{2} \mathrm{O}_{2}(\mu \mathrm{M})$

- Nrf2-KD

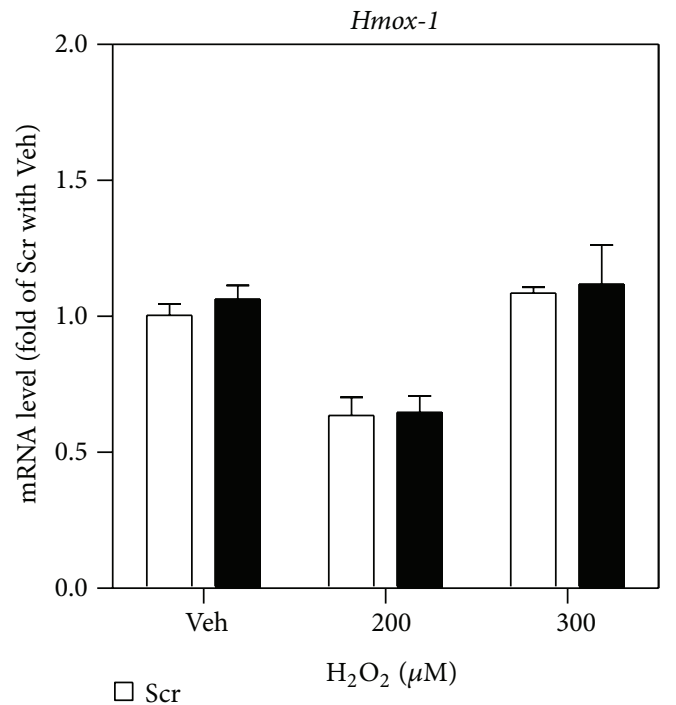

- Nrf2-KD

FIgURE 3: Reduced expression of antioxidant genes in Nrf2-KD cells under basal and $\mathrm{H}_{2} \mathrm{O}_{2}$-treated conditions. Cells were treated with $\mathrm{H}_{2} \mathrm{O}_{2}$ for $6 \mathrm{hrs}$. Values are means \pm SD. $n=3-6 .{ }^{*} P<0.05$ versus Scr with the same treatment. 


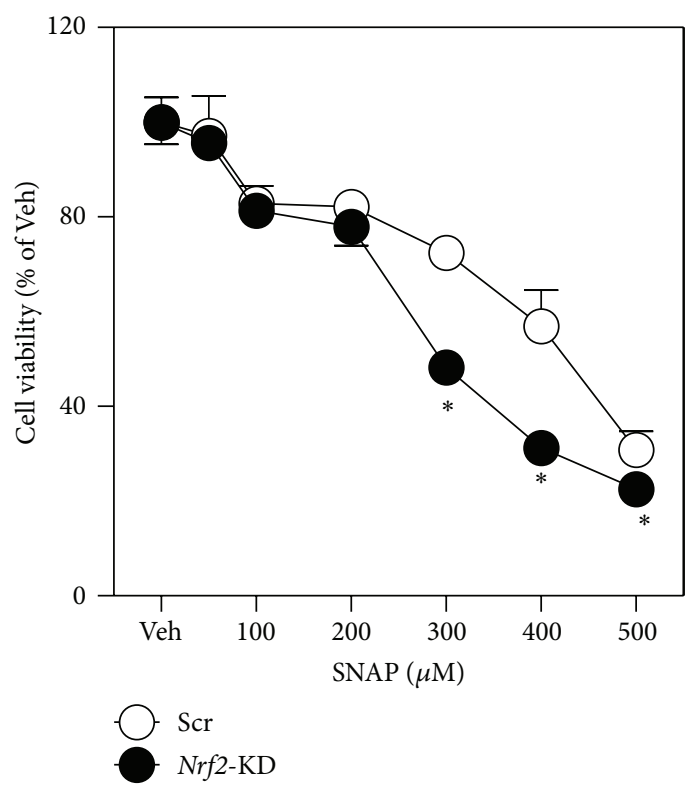

(a)

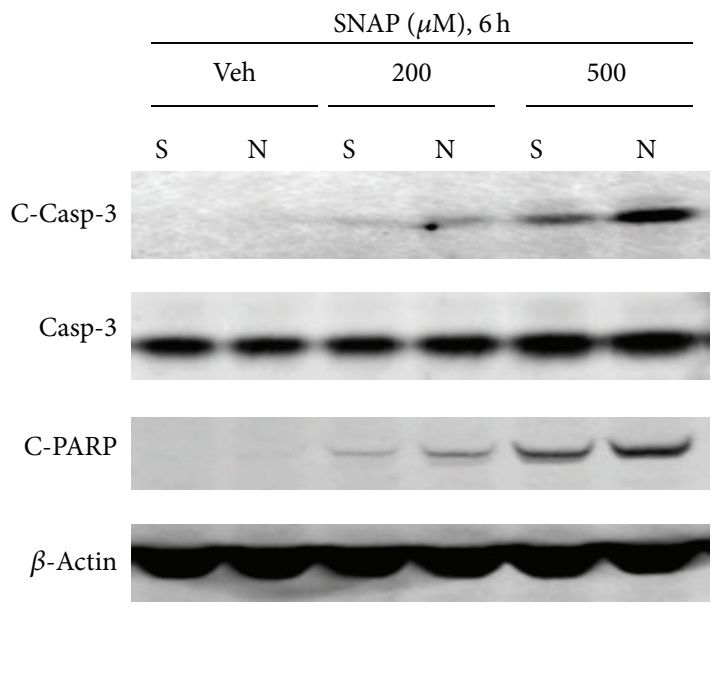

(b)

FIGURE 4: Nrf2-KD MIN6 cells are vulnerable to SNAP-induced cytotoxicity. (a) Following a 24 hr exposure to SNAP cell viability was assessed by MTT assay. (b) Immunoblotting of cleaved Caspase-3 (C-Casp-3), Caspase-3 (Casp-3), and cleaved PARP (C-PARP) in MIN6 cells exposed to SNAP for indicated time and concentrations. $\beta$-Actin was used as a loading control.

were significantly attenuated by Nrf2 silencing under basal or $\mathrm{H}_{2} \mathrm{O}_{2}$-challenged conditions, suggesting that the NRF2ARE system is important in determining cell fate in response to acute oxidative stress. However, there was no significant induction of the ARE-dependent genes in response to $\mathrm{H}_{2} \mathrm{O}_{2}$ challenge in Scr cells, suggesting that $\mathrm{H}_{2} \mathrm{O}_{2}$ is not a strong NRF2 activator at low concentrations $(<0.3 \mathrm{mM})$ in MIN6 cells. In addition, the mRNA expression of Nqo1 and Hmox1 showed no significant difference between Scr and Nrf2$\mathrm{KD}$ cells under $\mathrm{H}_{2} \mathrm{O}_{2}$ treatment, which is distinct from the patterns induced by other stressors, including tBHQ (Figure 1(c)) and arsenite [17].

To extend the findings above, the susceptibility of scramble and Nrf2-KD MIN6 cells to a NO-releasing compound SNAP-induced cytotoxicity was determined. Compared to Scr cells, Nrf2-KD MIN6 cells were more vulnerable to SNAPinduced reduction in cell viability (Figure 4(a)) and apoptosis (Figure 4(b)).

To validate the key findings observed in MIN6 cells, $\mathrm{H}_{2} \mathrm{O}_{2}$-induced cell damage was determined in cultured islets isolated from wild-type and Nrf2-I- mice. As shown in Figure 5, Nrf2-I- islets showed reduced expression of Nqo1 and Gclc (Figure 5(a)), confirming that the ARE-dependent transcription was attenuated in the tissues. Consistent with the conclusions obtained in MIN6 cells, Nrf2-/- islets exhibited more serious damage than $\mathrm{Nrf2+/}+$ islets as determined by morphology changes in response to $\mathrm{H}_{2} \mathrm{O}_{2}$ exposure (Figures 5(b) and 5(c)).

3.3. Preactivation of NRF2 Protects MIN6 Cells against $\mathrm{H}_{2} \mathrm{O}_{2}$ Induced Cytotoxicity and Apoptosis. To further determine the protective role of NRF2-mediated antioxidant response in acute oxidative stress-induced $\beta$-cell damage, the effects of preactivation of NRF2 by multiple NRF2 activators on $\mathrm{H}_{2} \mathrm{O}_{2}$-induced cytotoxicity and apoptosis were determined in MIN6 cells. As shown in Figure 6, a 4 hr pretreatment with either CDDO-Im (Figure 6(a)) or DMF (Figure 6(c)) significantly enhanced ARE-luciferase activity in a concentrationdependent manner, indicating both compounds are potent activators of NRF2-mediated antioxidant response in the cells. Pretreatment of MIN6 cells individually with these two activators significantly attenuated $\mathrm{H}_{2} \mathrm{O}_{2}$-induced cytotoxicity (Figures 6(b) and 6(d)). In addition, pretreatment with another NRF2 activator, tBHQ $(10 \mu \mathrm{M})$, also substantially protected MIN6 cells from the $\mathrm{H}_{2} \mathrm{O}_{2}$-induced apoptosis as measured by elevation of C-Casp-3 and C-PARP (Figure 6(e)). Thus, preactivation of NRF2 by either CDDO-Im, DMF, or tBHQ may partially protect MIN6 cells against $\mathrm{H}_{2} \mathrm{O}_{2}$ induced acute cell damage.

\section{Discussion}

The impairment of pancreatic $\beta$-cell function is critical in the pathophysiology of both type 1 and type 2 diabetes. Amidst the various mechanisms proposed for $\beta$-cell dysfunction and their roles in the progression of $\beta$-cell damage, oxidative stress has been proposed as a common denominator [27]. The present study found that acute exposure of MIN6 $\beta$-cells or isolated mouse islets to the most common oxidative stressors, $\mathrm{H}_{2} \mathrm{O}_{2}$ or $\mathrm{NO}$, resulted in cell damage in a concentrationand time-dependent manner. Nrf2-KD MIN6 $\beta$-cells and $N r f 2-/-$ islets were vulnerable to $\mathrm{H}_{2} \mathrm{O}_{2}$ or SNAP-induced cytotoxicity and apoptosis. In addition, pretreatment of MIN6 $\beta$-cells with a variety of NRF2 activators protected 


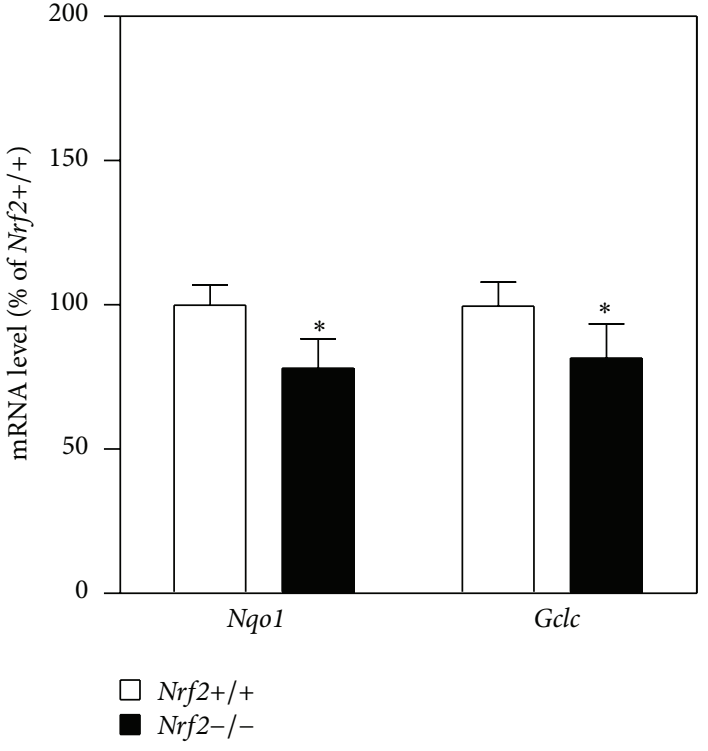

(a)

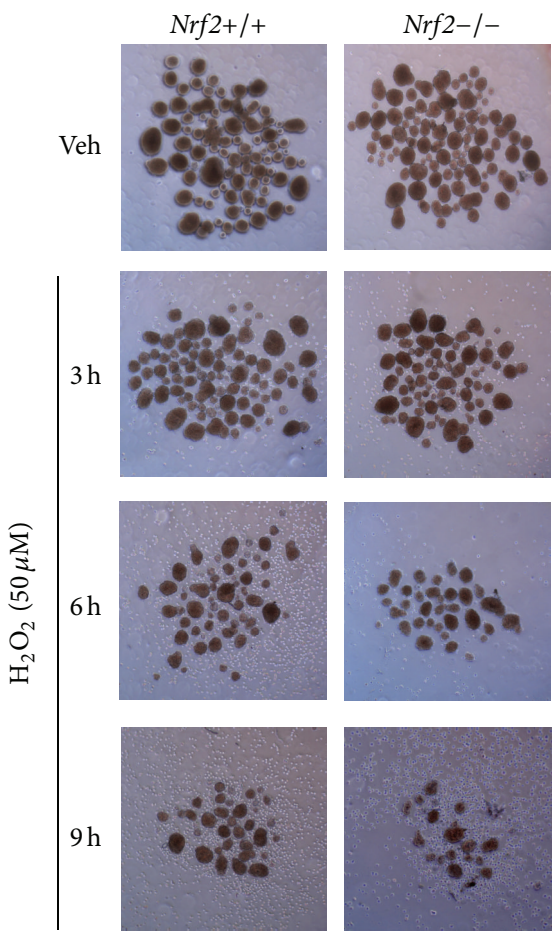

(b)

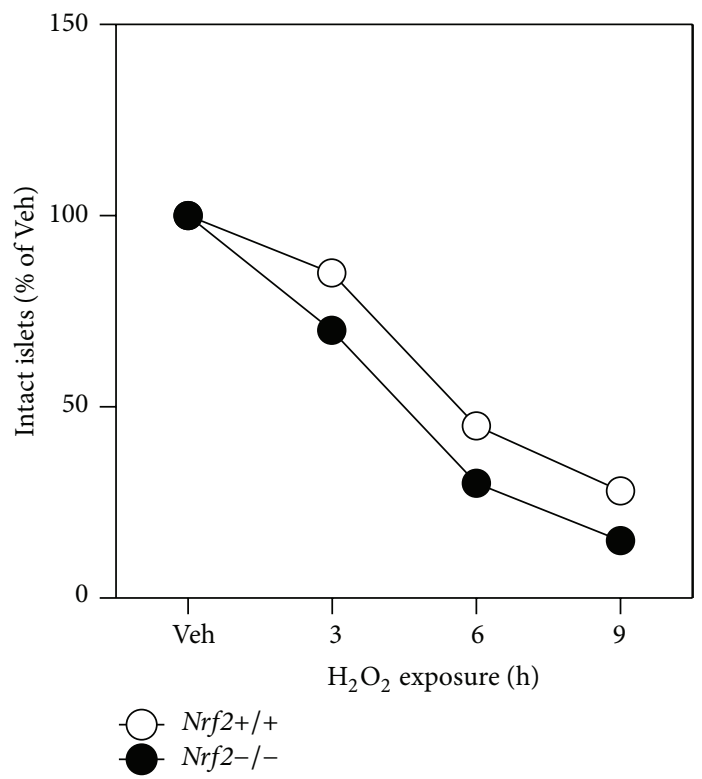

(c)

FiguRE 5: Deficiency of Nrf2 results in reduced expression of antioxidant genes and sensitization to $\mathrm{H}_{2} \mathrm{O}_{2}$-induced damage in isolated mouse islets. (a) Nrf2-l- islets exhibit reduced expression of antioxidant genes. Total RNA was extracted from isolated islets that were cultured for 48 hrs. $n=3 .{ }^{*} \mathrm{P}<0.05$ versus Nrf2+/+ islets. (b) Representative images of cultured islets that have been exposed to $50 \mu \mathrm{M} \mathrm{H}_{2} \mathrm{O}_{2}$ for indicated time. The islets were examined by an Olympus SZX7 Zoom Stereomicroscope (4x). (c) Count of intact islets left following $\mathrm{H}_{2} \mathrm{O}_{2}$ exposure as shown in (b).

the cells from high levels of $\mathrm{H}_{2} \mathrm{O}_{2}$-induced cell damage. These findings clearly demonstrate that NRF2-mediated antioxidant response protects $\beta$-cells from acute oxidative stressinduced cell damage.
Oxidative stress in pancreatic $\beta$-cells is generally induced by glucotoxicity, lipotoxicity, and/or inflammation in different stages of diabetes [27]. Although ROS and RNS are critical signaling molecules mediating a variety of signaling 


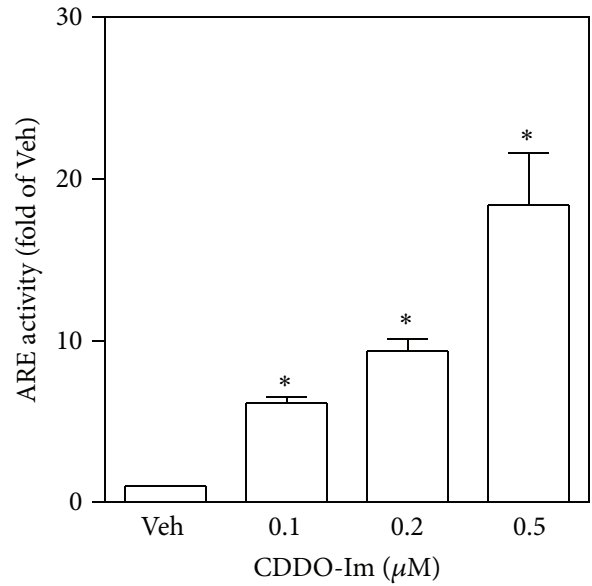

(a)

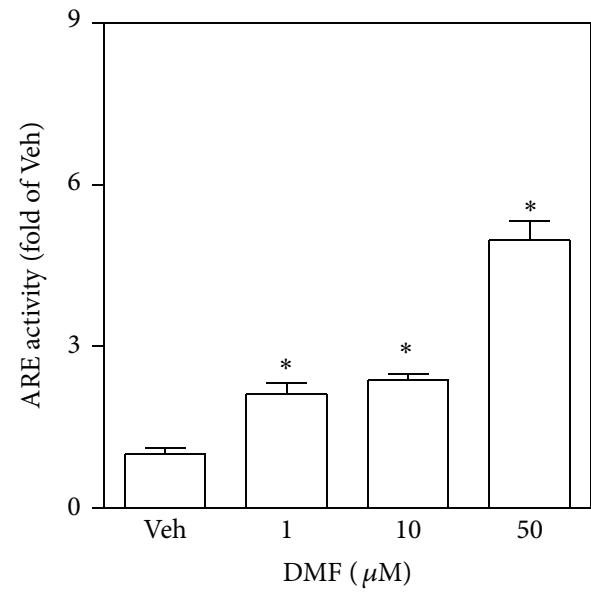

(c)

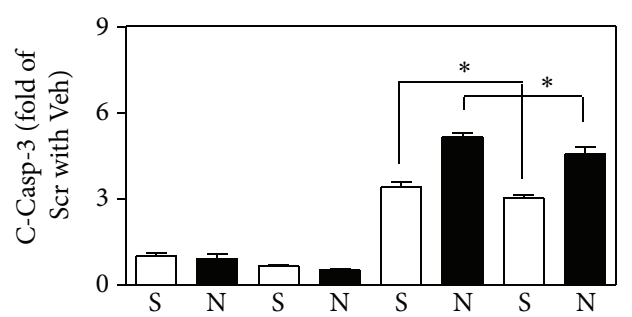

C-Casp-3

$\beta$-Actin

$\mathrm{H}_{2} \mathrm{O}_{2}(200 \mu \mathrm{M}), 6 \mathrm{~h}$ tBHQ $(10 \mu \mathrm{M}), 16 \mathrm{~h}$

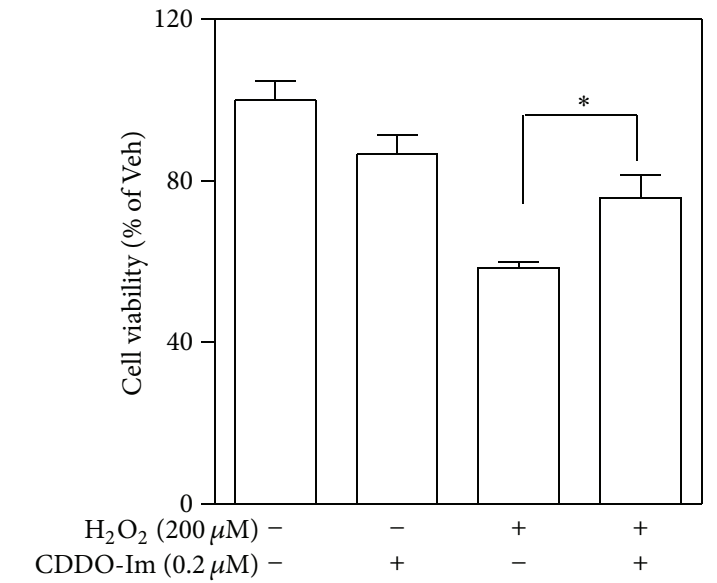

(b)

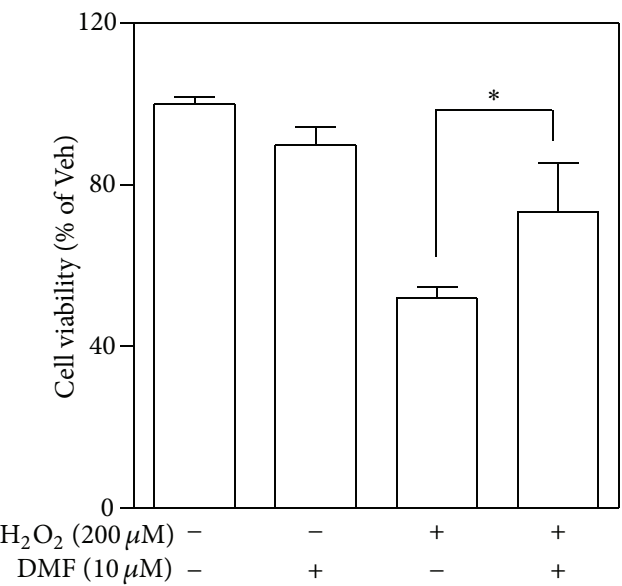

(d)

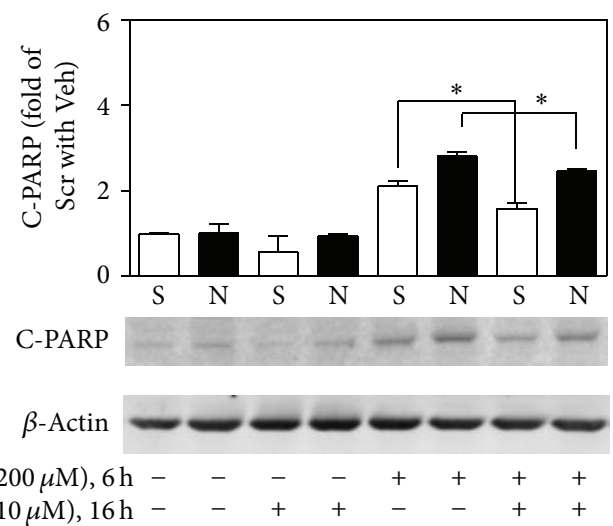

(e)

FIGURE 6: Preactivation of NRF2 protects MIN6 cells from $\mathrm{H}_{2} \mathrm{O}_{2}$-induced cytotoxicity. ((a) and (c)) ARE-luciferase activity measured in MIN6 cells. The cells were challenged with CDDO-Im (a) or DMF (b) for 4 hrs. ((b) and (d)) Effects of CDDO-Im and DMF pretreatment on $\mathrm{H}_{2} \mathrm{O}_{2}$-induced cytotoxicity. Following a $4 \mathrm{hr}$ pretreatment with CDDO-Im (b) or DMF (d) cells were exposed to $\mathrm{H}_{2} \mathrm{O}_{2}$ for 12 hrs. Cell viability was assessed by MTT assay. (e) Cells were pretreated with $10 \mu \mathrm{M}$ tBHQ for $16 \mathrm{hrs}$ followed by a $6 \mathrm{hr} \mathrm{H}_{2} \mathrm{O}_{2}$ exposure. Apoptosis markers cleaved Caspase-3 (C-Casp-3) and cleaved PARP (C-PARP) were determined using immunoblotting and quantified by Image $1.44 . n=3$. ${ }^{*} P<0.05$ versus nonpretreated cells with the same treatment. 
cascades [14], they both lead to cell damage at high levels. Partially due to low basal expression of many antioxidant enzymes, $\beta$-cells are relatively vulnerable to oxidative damage induced by excessive ROS and/or RNS [20]. In the present study, we found that $\mathrm{H}_{2} \mathrm{O}_{2}$ may induce cell damage in MIN6 cells and cultured islets at a concentration as low as $50 \mu \mathrm{M}$, which is dramatically lower than the concentrations we used in human keratinocytes to activate NRF2 [25]. Under oxidative stress, most of cells may upregulate their intracellular antioxidant capacity by transcriptional induction of many antioxidant and phase II detoxification enzymes via NRF2mediated antioxidant response and thus protect the cells from oxidative damage $[15,18,19,28-30]$. Our previous studies have elucidated that NRF2 also plays a critical role in pancreatic $\beta$-cell defense against oxidative/electrophilic stress [17]. Abolishment of the NRF2-mediated antioxidant response by targeted disruption of the Nrf2 gene in MIN6 cells and mouse islets increased their susceptibility to environmental oxidative stressor arsenic-induced cytotoxicity and/or apoptosis [17]. Preactivation of NRF2 with tBHQ significantly protects MIN6 cells from arsenic-induced acute cytotoxicity in Nrf2dependent manner [17]. Recently, Yagishita et al. presented detailed in vivo evidence from four genetically engineered mouse models to demonstrate that NRF2 induction prevents oxidative and nitrosative stress-induced oxidative damage in pancreatic $\beta$-cells [31]. In the current study we used the most common oxidative stressors and two genetically engineered cell models to confirm that NRF2-mediated antioxidant response protects pancreatic $\beta$-cell against oxidative stressinduced cell damage in vitro and ex vivo. These new findings provided additional evidence to support that NRF2-mediated antioxidant response protects pancreatic $\beta$-cell against acute ROS or RNS-induced cell damage.

Given that NRF2-mediated antioxidant response plays critical role in cell defense, NRF2 has been considered as a valuable therapeutic target. CDDO-Im is one of the most potent synthetic triterpenoids shown to activate NRF2 and induce phase II detoxifying and antioxidant enzymes. It was firstly investigated in protecting against aflatoxininduced tumorigenesis in liver $[32,33]$. Recently, it has been used for the treatment of chronic kidney disease, cancer, and other diseases [34-36]. DMF is a newly found NRF2 activator and has been used for the treatment of psoriasis [37] and more recently for multiple sclerosis [38]. CDDOIm and DMF have been reported to protect endothelial cells and prevent vascular injury via NRF2 activation $[39,40]$. In the present study, we found that CDDO-Im and DMF pretreatments may dramatically enhance the activity of AREdependent transcription in pancreatic $\beta$-cells and protect the cells against acute oxidative stress-induced cell damage. Together with the protective effect by another well-known NRF2 activator, tBHQ, we conclude that preactivation of NRF2 may protect pancreatic $\beta$-cells from acute oxidative stress-induced cell damage.

Although ROS and RNS have been demonstrated to be destructive factors at high levels, they also function as physiological signaling molecules mediating a variety of physiological processes, including GSIS in $\beta$-cells $[3,4]$. In the case where ROS serve as cell signaling molecules, persistent elevation of endogenous antioxidants could diminish such a signal. Thus, persistent activation of NRF2-mediated antioxidant response has the potential to cause an undesirable effect. Our previous study showed that persistent NRF2 activation by prolonged arsenic exposure blunts glucose-stimulated ROS signaling to mediate GSIS in pancreatic $\beta$-cells [22]. Therefore, we have proposed that NRF2-mediated antioxidant response plays paradoxical roles in $\beta$-cell function. On the one hand, this pathway protects cells from oxidative damage and possible cell death, thus minimizing oxidative damagerelated impairment in $\beta$-cell dysfunction; on the other hand, the induction of endogenous antioxidants in the presence of oxidative stress may blunt ROS signal, resulting in reduced GSIS $[41,42]$. Considering that glucose metabolism-derived ROS are involved in regulating GSIS in $\beta$-cells and persistent activation of NRF2 blunts glucose-triggered ROS signaling and GSIS, we conclude that NRF2 may play distinct roles in pancreatic $\beta$-cell dysfunction that occurs in different stages of diabetes.

\section{Conclusions}

The present study demonstrated that NRF2-mediated antioxidant response protects pancreatic $\beta$-cells from oxidative stress-induced cell damage. In light of the inhibitory effect of NRF2-mediated antioxidant response on ROS signaling in $\beta$-cell GSIS, the present study highlights distinct roles that NRF2 may play in pancreatic $\beta$-cell dysfunction that occurs in different stages of diabetes. Thus, more detailed investigations focusing on the exact mode of ROS and various endogenous antioxidants in regulating GSIS and $\beta$ cell survival during different stages of diabetes are needed.

\section{Abbreviations}

$\begin{array}{ll}\text { ARE: } & \text { Antioxidant response element } \\ \text { CDDO-Im: } & \begin{array}{l}\text { 1-[2-Cyano-3,12-dioxooleana-1,9(11)- } \\ \text { dien-28-oyl]imidazole }\end{array} \\ \text { C-Casp-3: } & \text { Cleaved Caspase-3 } \\ \text { CM-H }{ }_{2} \text { DCFDA: } & \text { 5-(and-6)-Chloromethyl-2' } \text { ' }^{\prime} \text { - } \\ & \text { dichlorodihydrofluorescein diacetate, } \\ & \text { acetyl ester } \\ \text { C-PARP: } & \text { Cleaved PARP } \\ \text { DMEM: } & \text { Dulbecco's modified Eagle's medium } \\ \text { DMF: } & \text { Dimethyl fumarate } \\ \text { FBS: } & \text { Fetal bovine serum } \\ \text { Gclc: } & \text { Glutamate-cysteine ligase catalytic } \\ & \text { subunit } \\ \text { GSH: } & \text { Glutathione } \\ \text { GSIS: } & \text { Glucose-stimulated insulin secretion } \\ \text { Hmox-1: } & \text { Heme oxygenase 1 } \\ \mathrm{H}_{2} \mathrm{O}_{2}: & \text { Hydrogen peroxide } \\ \text { NO: } & \text { Nitric oxide } \\ \text { Nqo1: } & \text { NAD(P)H quinone oxidoreductase 1 } \\ \text { Nrf2: } & \text { Nuclear factor E2-related factor 2 } \\ \text { PARP: } & \text { Poly(ADP-ribose)polymerase } \\ \text { Prdxl: } & \text { Peroxiredoxin-1 } \\ \text { ROS: } & \text { Reactive oxygen species }\end{array}$


RNS: Reactive nitrogen species

SNAP: S-Nitroso-N-acetylpenicillamine

Sod1: Superoxide dismutase-1

Srxn1: Sulfiredoxin 1

tBHQ: tert-Butylhydroquinone.

\section{Conflict of Interests}

The authors declare that they have no conflict of interests.

\section{Acknowledgments}

This work was supported in part by the Startup Funding of China Medical University (Jingbo Pi), Liaoning Pandeng Scholar Program (Jingbo Pi), the Key Laboratory of Public Health Safety (Fudan University), Ministry of Education, China, GW2014-1 (Jingqi Fu), and the Chinese Nature Science Foundation 81402635 (Jingqi Fu), 81102156 (Rui Zhao), and 81372943 (Rui Zhao).

\section{References}

[1] T. L. Van Belle, K. T. Coppieters, and M. G. von Herrath, "Type 1 diabetes: Etiology, immunology, and therapeutic strategies," Physiological Reviews, vol. 91, no. 1, pp. 79-118, 2011.

[2] M. Cnop, N. Welsh, J.-C. Jonas, A. Jörns, S. Lenzen, and D. L. Eizirik, "Mechanisms of pancreatic $\beta$-cell death in type 1 and type 2 diabetes: many differences, few similarities," Diabetes, vol. 54, supplement 2, pp. S97-S107, 2005.

[3] M. Saadeh, T. C. Ferrante, A. Kane, O. Shirihai, B. E. Corkey, and J. T. Deeney, "Reactive oxygen species stimulate insulin secretion in rat pancreatic islets: studies using mono-oleoylglycerol," PLoS ONE, vol. 7, no. 1, Article ID e30200, 2012.

[4] J. Pi, Y. Bai, Q. Zhang et al., "Reactive oxygen species as a signal in glucose-stimulated insulin secretion," Diabetes, vol. 56, no. 7, pp. 1783-1791, 2007.

[5] C. Leloup, C. Tourrel-Cuzin, C. Magnan et al., "Mitochondrial reactive oxygen species are obligatory signals for glucoseinduced insulin secretion," Diabetes, vol. 58, no. 3, pp. 673-681, 2009.

[6] W. Dröge, "Free radicals in the physiological control of cell function," Physiological Reviews, vol. 82, no. 1, pp. 47-95, 2002.

[7] J. L. Evans, I. D. Goldfine, B. A. Maddux, and G. M. Grodsky, "Are oxidative stress-activated signaling pathways mediators of insulin resistance and beta-cell dysfunction?" Diabetes, vol. 52, no. 1, pp. 1-8, 2003.

[8] J. Størling, J. Binzer, A. K. Andersson et al., "Nitric oxide contributes to cytokine-induced apoptosis in pancreatic beta cells via potentiation of JNK activity and inhibition of Akt," Diabetologia, vol. 48, no. 10, pp. 2039-2050, 2005.

[9] T. S. Isbell, C.-W. Sun, L.-C. Wu et al., "SNO-hemoglobin is not essential for red blood cell-dependent hypoxic vasodilation," Nature Medicine, vol. 14, no. 7, pp. 773-777, 2008.

[10] F. Taqatqeh, E. Mergia, A. Neitz, U. T. Eysel, D. Koesling, and T. Mittmann, "More than a retrograde messenger: nitric oxide needs two cGMP pathways to induce hippocampal long-term potentiation," Journal of Neuroscience, vol. 29, no. 29, pp. 93449350, 2009.
[11] J. W. Coleman, "Nitric oxide in immunity and inflammation," International Immunopharmacology, vol. 1, no. 8, pp. 1397-1406, 2001.

[12] H. Wiseman and B. Halliwell, "Damage to DNA by reactive oxygen and nitrogen species: role in inflammatory disease and progression to cancer," Biochemical Journal, vol. 313, part 1, pp. 17-29, 1996.

[13] M. P. Murphy, "Nitric oxide and cell death," Biochimica et Biophysica Acta, vol. 1411, no. 2-3, pp. 401-414, 1999.

[14] G. P. Meares, D. Fontanilla, K. A. Broniowska, T. Andreone, J. R. Lancaster Jr., and J. A. Corbett, "Differential responses of pancreatic beta-cells to ROS and RNS," The American Journal of Physiology-Endocrinology and Metabolism, vol. 304, no. 6, pp. E614-E622, 2013.

[15] T. Nguyen, P. J. Sherratt, and C. B. Pickett, "Regulatory mechanisms controlling gene expression mediated by the antioxidant response element," Annual Review of Pharmacology and Toxicology, vol. 43, pp. 233-260, 2003.

[16] S. B. Cullinan, J. D. Gordan, J. Jin, J. W. Harper, and J. A. Diehl, "The Keap1-BTB protein is an adaptor that bridges Nrf2 to a Cul3-based E3 ligase: oxidative stress sensing by a Cul3-Keap1 ligase," Molecular and Cellular Biology, vol. 24, no. 19, pp. 84778486, 2004.

[17] B. Yang, J. Fu, H. Zheng et al., "Deficiency in the nuclear factor E2-related factor 2 renders pancreatic $\beta$-cells vulnerable to arsenic-induced cell damage," Toxicology and Applied Pharmacology, vol. 264, no. 3, pp. 315-323, 2012.

[18] E. L. Donovan, J. M. McCord, D. J. Reuland, B. F. Miller, and K. L. Hamilton, "Phytochemical activation of Nrf2 protects human coronary artery endothelial cells against an oxidative challenge," Oxidative Medicine and Cellular Longevity, vol. 2012, Article ID 132931, 9 pages, 2012.

[19] T. Jiang, Z. Huang, Y. Lin, Z. Zhang, D. Fang, and D. D. Zhang, "The protective role of Nrf2 in streptozotocin-induced diabetic nephropathy," Diabetes, vol. 59, no. 4, pp. 850-860, 2010.

[20] M. Tiedge, S. Lortz, J. Drinkgern, and S. Lenzen, "Relation between antioxidant enzyme gene expression and antioxidative defense status of insulin-producing cells," Diabetes, vol. 46, no. 11, pp. 1733-1742, 1997.

[21] M. C. Haigis, R. Mostoslavsky, K. M. Haigis et al., "SIRT4 inhibits glutamate dehydrogenase and opposes the effects of calorie restriction in pancreatic beta cells," Cell, vol. 126, no. 5, pp. 941-954, 2006.

[22] J. Fu, C. G. Woods, E. Yehuda-Shnaidman et al., "Low level arsenic impairs glucose-stimulated insulin secretion in pancreatic beta-cells: involvement of cellular adaptive response to oxidative stress," Environmental Health Perspectives, vol. 118, no. 6, pp. 864-870, 2010.

[23] K. Itoh, T. Chiba, S. Takahashi et al., "An Nrf2/small Maf heterodimer mediates the induction of phase II detoxifying enzyme genes through antioxidant response elements," Biochemical and Biophysical Research Communications, vol. 236, no. 2, pp. 313-322, 1997.

[24] C. G. Woods, J. Fu, P. Xue et al., "Dose-dependent transitions in Nrf2-mediated adaptive response and related stress responses to hypochlorous acid in mouse macrophages," Toxicology and Applied Pharmacology, vol. 238, no. 1, pp. 27-36, 2009.

[25] J. Pi, W. Qu, J. M. Reece, Y. Kumagai, and M. P. Waalkes, "Transcription factor Nrf2 activation by inorganic arsenic in cultured keratinocytes: involvement of hydrogen peroxide," Experimental Cell Research, vol. 290, no. 2, pp. 234-245, 2003. 
[26] R. Zhao, B. Yang, L. Wang et al., "Curcumin protects human keratinocytes against inorganic arsenite-induced acute cytotoxicity through an NRF2-dependent mechanism," Oxidative Medicine and Cellular Longevity, vol. 2013, Article ID 412576, 11 pages, 2013.

[27] L. Rochette, M. Zeller, Y. Cottin, and C. Vergely, "Diabetes, oxidative stress and therapeutic strategies," Biochimica et Biophysica Acta-General Subjects, vol. 1840, no. 9, pp. 2709-2729, 2014.

[28] K. Itoh, K. I. Tong, and M. Yamamoto, "Molecular mechanism activating Nrf2-Keap1 pathway in regulation of adaptive response to electrophiles," Free Radical Biology and Medicine, vol. 36, no. 10, pp. 1208-1213, 2004.

[29] X. J. Wang, Z. Sun, W. Chen, K. E. Eblin, J. A. Gandolfi, and D. D. Zhang, "Nrf2 protects human bladder urothelial cells from arsenite and monomethylarsonous acid toxicity," Toxicology and Applied Pharmacology, vol. 225, no. 2, pp. 206-213, 2007.

[30] H.-Y. Cho, A. E. Jedlicka, S. P. M. Reddy et al., "Role of NRF2 in protection against hyperoxic lung injury in mice," American Journal of Respiratory Cell and Molecular Biology, vol. 26, no. 2, pp. 175-182, 2002.

[31] Y. Yagishita, T. Fukutomi, A. Sugawara et al., "Nrf2 protects pancreatic $\beta$-cellss from oxidative and nitrosative stress in diabetic model mice," Diabetes, vol. 63, no. 2, pp. 605-618, 2014.

[32] K. Liby, T. Hock, M. M. Yore et al., "The synthetic triterpenoids, CDDO and CDDO-imidazolide, are potent inducers of heme oxygenase-1 and Nrf2/ARE signaling," Cancer Research, vol. 65, no. 11, pp. 4789-4798, 2005.

[33] M. S. Yates, M.-K. Kwak, P. A. Egner et al., "Potent protection against aflatoxin-induced tumorigenesis through induction of Nrf2-regulated pathways by the triterpenoid 1-[2-cyano-3-,12dioxooleana-1, 9(11)-dien-28-oyl]imidazole," Cancer Research, vol. 66, no. 4, pp. 2488-2494, 2006.

[34] J. L. Townson, I. C. MacDonald, K. T. Liby et al., "The synthetic triterpenoid CDDO-Imidazolide suppresses experimental liver metastasis," Clinical and Experimental Metastasis, vol. 28, no. 3, pp. 309-317, 2011.

[35] Y. Tanaka, L. M. Aleksunes, M. J. Goedken et al., "Coordinated induction of $\mathrm{Nrf} 2$ target genes protects against iron nitrilotriacetate (FeNTA)-induced nephrotoxicity," Toxicology and Applied Pharmacology, vol. 231, no. 3, pp. 364-373, 2008.

[36] I. Samudio, M. Konopleva, N. Hail Jr. et al., "2-Cyano-3,12dioxooleana-1,9-dien-28-imidazolide (CDDO-Im) directly targets mitochondrial glutathione to induce apoptosis in pancreatic cancer," The Journal of Biological Chemistry, vol. 280, no. 43, pp. 36273-36282, 2005.

[37] M. Stoppe, E. Thomä, U. G. Liebert et al., "Cerebellar manifestation of PML under fumarate and after efalizumab treatment of psoriasis," Journal of Neurology, vol. 261, no. 5, pp. 1021-1024, 2014.

[38] R. H. Scannevin, S. Chollate, M.-Y. Jung et al., "Fumarates promote cytoprotection of central nervous system cells against oxidative stress via the nuclear factor (erythroid-derived 2)like 2 pathway," Journal of Pharmacology and Experimental Therapeutics, vol. 341, no. 1, pp. 274-284, 2012.

[39] C. J. Oh, S. Park, J. Kim et al., "Dimethylfumarate attenuates restenosis after acute vascular injury by cell-specific and Nrf2dependent mechanisms," Redox Biology, vol. 2, pp. 855-864, 2014.

[40] X. Wang, J. A. Bynum, S. Stavchansky, and P. D. Bowman, "Cytoprotection of human endothelial cells against oxidative stress by 1-[2-cyano-3,12-dioxooleana-1,9(11)-dien-28-oyl]imidazole (CDDO-Im): application of systems biology to understand the mechanism of action," European Journal of Pharmacology, vol. 734, no. 1, pp. 122-131, 2014.

[41] J. Pi, Q. Zhang, J. Fu et al., "ROS signaling, oxidative stress and Nrf2 in pancreatic beta-cell function," Toxicology and Applied Pharmacology, vol. 244, no. 1, pp. 77-83, 2010.

[42] S. Collins, J. Pi, and E. Yehuda-Shnaidman, "Uncoupling and reactive oxygen species (ROS) - a double-edged sword for $\beta$ cell function? 'moderation in all things"' Best Practice and Research: Clinical Endocrinology and Metabolism, vol. 26, no. 6, pp. 753-758, 2012. 


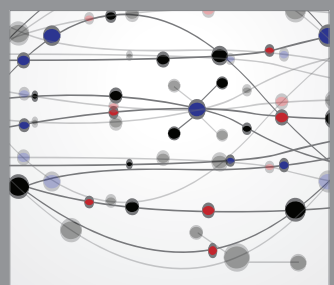

The Scientific World Journal
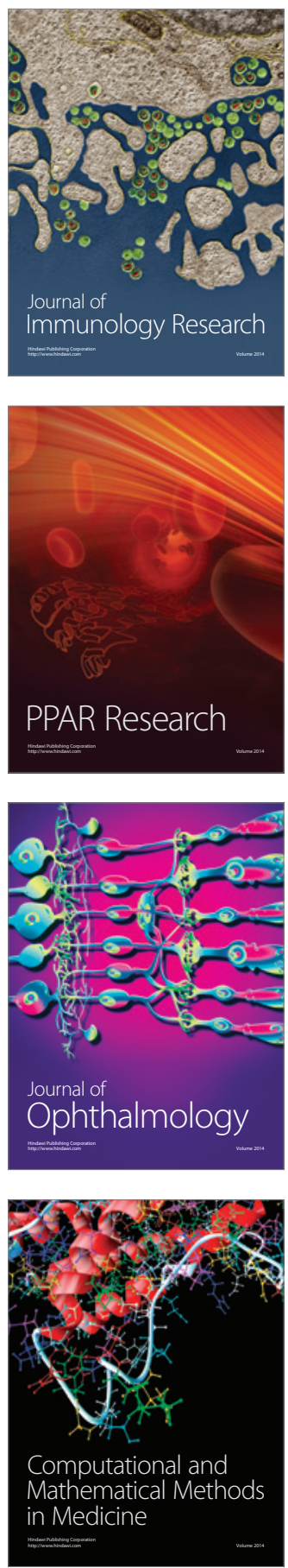

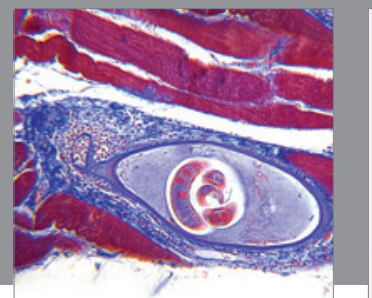

Gastroenterology

Research and Practice
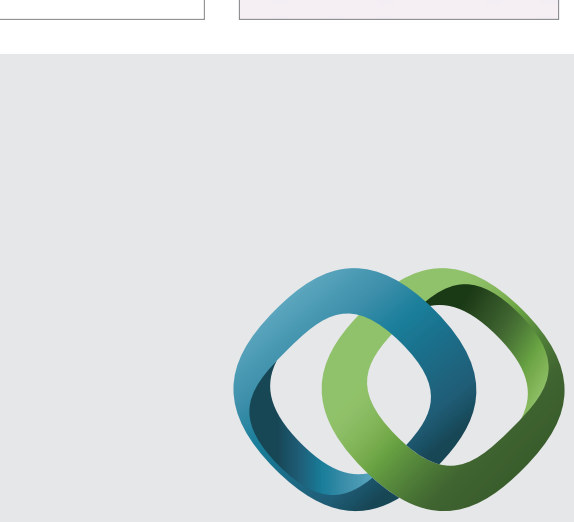

\section{Hindawi}

Submit your manuscripts at

http://www.hindawi.com
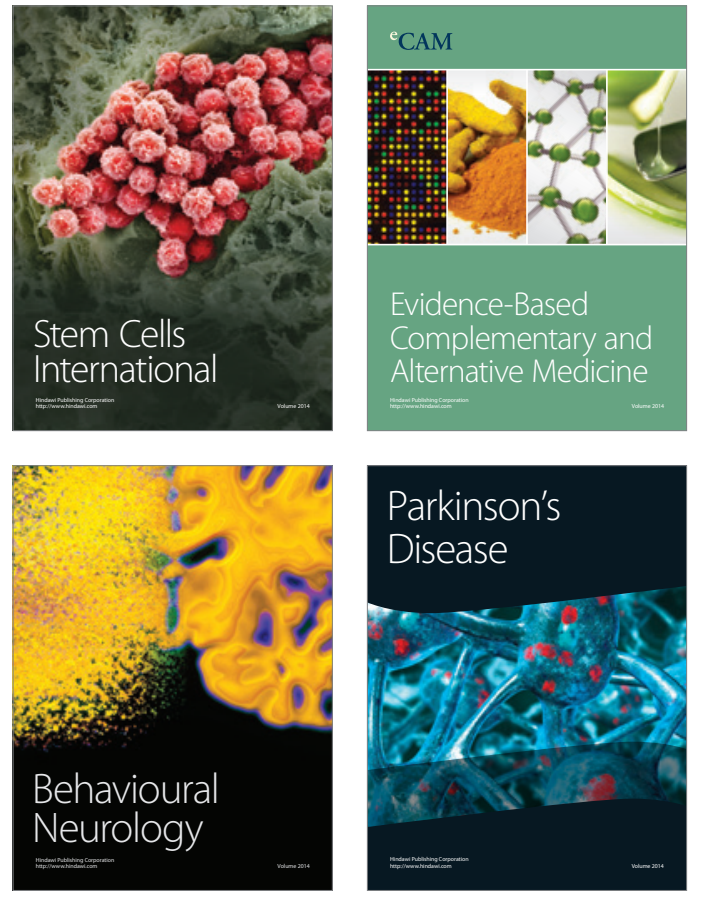
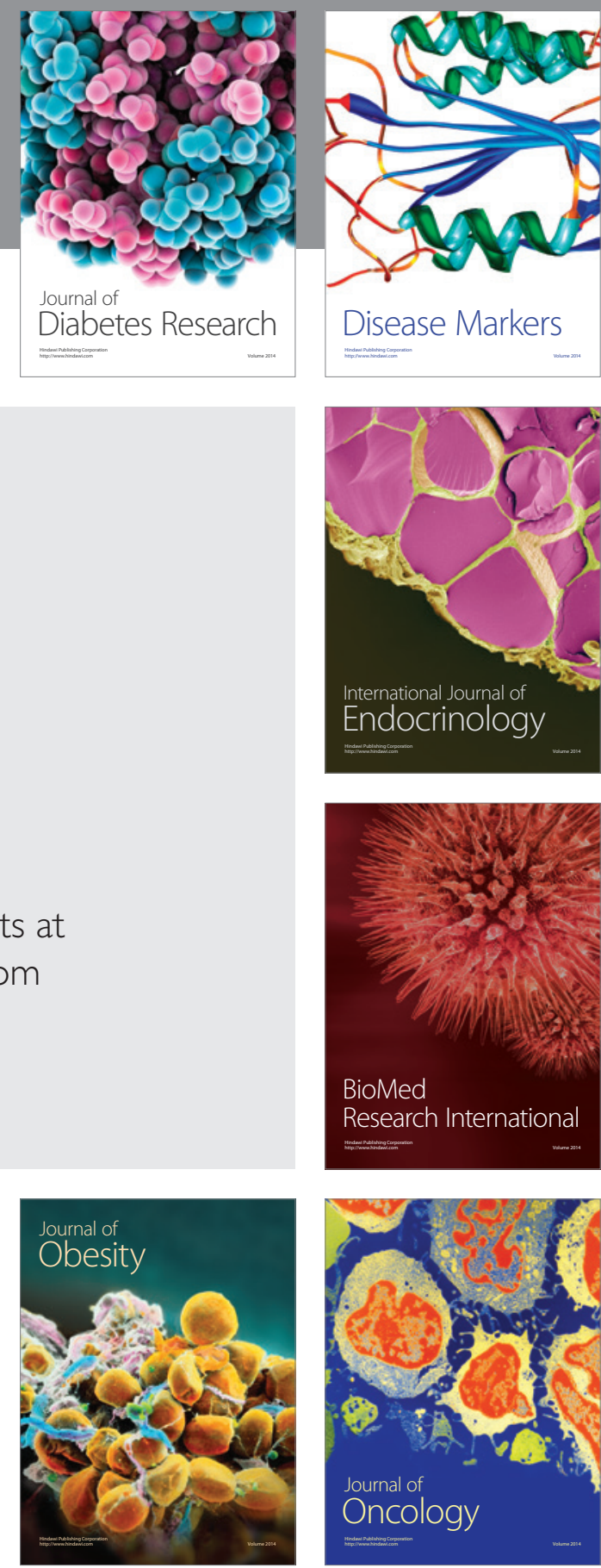

Disease Markers
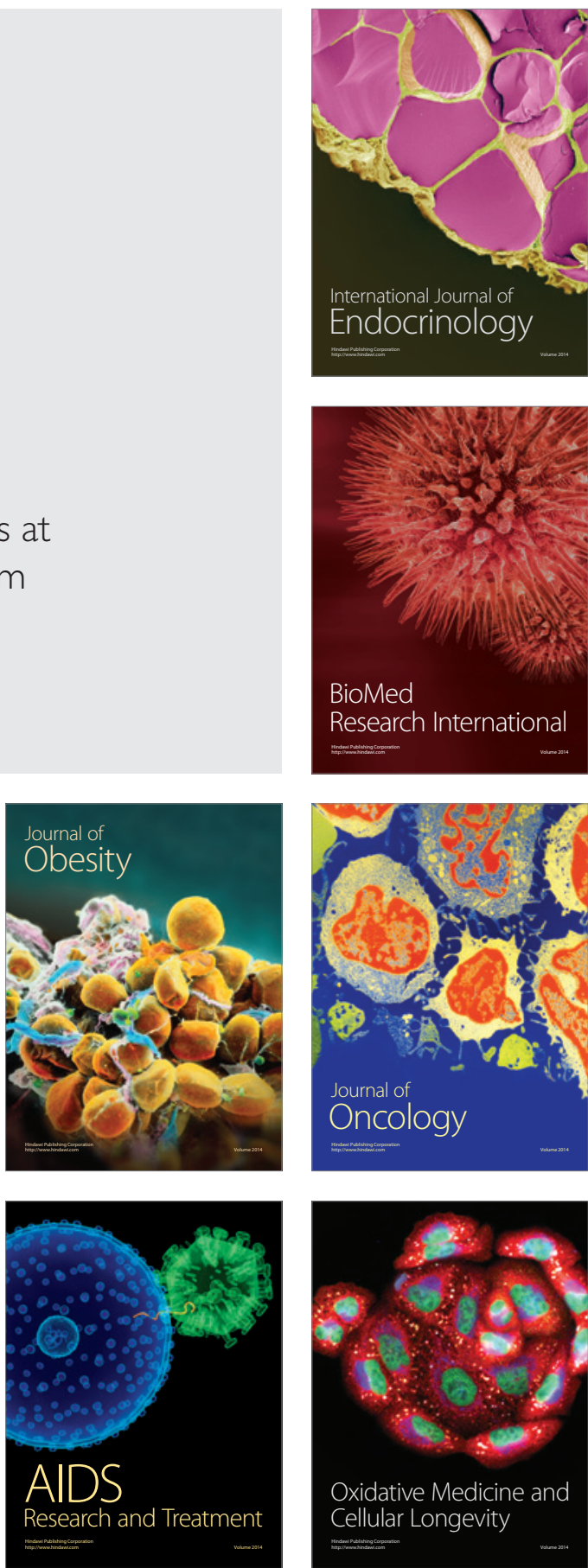